\title{
PERANAN GAYA MENGAJAR GURU FISIKA TERHADAP MINAT BELAJAR FISIKA SISWA KELAS IX MTS ISTIQLAL DELITUA
}

\author{
Surya Mahyudi \\ Jurusan Pendidikan Fisika \\ Program Pascasarjana Universitas Negeri Medan
}

\begin{abstract}
Abstrak. Penelitian ini bertujuan untuk mengetahui peranan gaya mengajar guru Fisika terhadap minat belajar Fisika siswa kelas IX MTs Istiqlal Delitua. Sampel penelitiannya siswa kelas IX MTs Istiqlal Delitua berjumlah 70 orang. Metode penelitian yang digunakan adalah metode deskriptif, pengumpulan data dilakukan dengan penyebaran angket. Untuk mengetahui hubungan kedua variabel digunakan koefisien korelasi product moment. Dari koefisien gaya mengajar guru, dikonversikan ke tabel interpretasi nilai r, untuk mengetahui peranan gaya mengajar guru fisika terhadap minat belajar fisika siswa. Ternyata ada peranan yang positif dan signifikan dari peranan gaya mengajar guru Fisika dalam proses pembelajaran terhadap minat siswa kelas IX MTs Istiqlal Delitua untuk belajar Fisika dengan koefisien korelasinya 0,596. Hal ini bersumber dari persentase rata-rata indikator peranan gaya mengajar sehingga perlu ditingkatkan lagi variasi gaya mengajar guru Fisika agar minat siswa belajar Fisika akan lebih besar.
\end{abstract}

Kata kunci: gaya mengajar, belajar, minat, minat belajar

\section{Pendahuluan}

Pendidikan merupakan penanaman nilainilai budaya bagi generasi penerus bangsa untuk mewujudkan cita-cita bangsa dan negara. Berhasil atau tidaknya pendidikan tersebut akan tercermin dari proses belajar mengajar. Dalam pelaksanaan pembelajaran di kelas, guru berperan sebagai penanggung jawab atas semua kegiatan belajar yang berlangsung karena guru dapat memberikan kemungkinan agar terjadi proses belajar mengajar yang efektif bagi siswa. Seorang guru selalu jadi perhatian para peserta didik dalam melaksanakan kegiatan pembelajaran. Mulai dari penampilan, cara berkomunikasi, cara berjalan, cara guru menyampaikan dan menjelaskan suatu materi pelajaran, serta bagaimana secara keseluruhan dapat menciptakan suasana belajar yang menyenangkan bagi siswa, termotivasi untuk mengikuti, mencerna setiap materi yang disampaikan oleh guru.

Ada beberapa gaya mengajar yang ditampilkan oleh guru sewaktu melaksanakan tugas pengajarannya, dari gaya yang ditampilkan itu sebagian mampu membuat siswa merasa bergairah dalam mengikuti jalannya pembelajaran dan termotivasi untuk mencapai prestasi yang maksimal. Setiap guru menampilkan gaya masing-masing dalam mengajar yang sedikit banyaknya mengandung perbedaan satu sama lain dan menimbulkan efek berbeda pula pada diri siswa dalam mengikuti pelajaran yang disampaikan oleh guru yang bersangkutan. Dalam proses belajar mengajar sering dijumpai dari tingkat SMP dan SMA, guru yang mengajar pelajaran Fisika sangat ditakuti meskipun hal ini tidak seluruh pada guru Fisika. Ditakuti dalam arti kekejamannya atau karena penampilan sang guru yang sedikit angker sehingga antara siswa dengan guru bidang studi eksakta kurang akrab. Karena yang demikian, maka dalam mengikuti pelajaran siswa tampak tegang. Dari ketegangan yang timbul pada proses belajar mengajar, akan terlahir mentalitas yang semu di antara siswa 
dalam mengikuti pelajaran, sehingga pada akhirnya minat siswa terhadap mata pelajaran Fisika menjadi berkurang.

Sesuai dengan latar belakang masalah, ada beberapa masalah yang teridentifikasi yaitu (1) Gaya guru menyampaikan, menjelaskan suatu materi pelajaran yang bervariasi dapat menciptakan suasana belajar yang menyenangkan bagi siswa sehingga siswa termotivasi untuk mengikuti dan mencerna setiap hal atau materi yang disampaikan oleh guru. (2) Gaya mengajar guru yang interaktif dengan siswa, akan tercipta suasana keakraban antara guru dengan siswa, sehingga siswa menaruh minat pada pelajaran yang diajarkan oleh guru. Batasan masalahnya adalah bagaimana minat belajar Fisika siswa jika guru Fisika menggunakan variasi gaya mengajar dalam proses belajar mengajar.

Berdasarkan latar belakang, identifikasi dan batasan masalah, rumusan masalah penelitian ini adalah Bagaimana Gaya Mengajar Guru Fisika Terhadap Minat Belajar Fisika Siswa Kelas IX MTs Istiqlal Delitua? Sedangkan tujuannya untuk mengetahui bagaimanakah gaya guru menyampaikan, menjelaskan suatu materi pelajaran agar dapat menciptakan suasana belajar yang menyenangkan bagi siswa sehingga siswa termotivasi untuk mengikuti dan mencerna setiap hal atau materi yang disampaikan oleh guru dan juga untuk mengetahui peranan gaya mengajar guru Fisika terhadap minat belajar Fisika siswa kelas IX MTs Istiqlal Delitua.

\section{Belajar}

Seseorang dikatakan telah belajar, apabila padanya terjadi perubahan tertentu, misalnya dari tidak tahu menjadi tahu. Akan tetapi tidak semua perubahan yang terjadi pada diri seseorang karena belajar, seperti seorang anak dari tidak dapat berdiri menjadi dapat berdiri. Perubahan-perubahan seperti yang dimaksud ini terjadi karena kematangan. Belajar adalah suatu perubahan dalam melaksanakan tugas yang terjadi sebagai hasil pengalaman dan tidak ada sangkut pautnya dengan kematangan rohaniah, atau faktor-faktor lain yang tidak berhubungan dengan kegiatan belajar (Purba, 2004). Jadi belajar merupakan suatu aktivitas mental yang berlangsung dalam interaksi aktif dengan lingkungan yang menghasilkan perubahan-perubahan dalam pengetahuan, pemahaman, keterampilan dan nilai sikap.

\section{Hasil Belajar Bersifat Relatif Menetap}

Perubahan akibat belajar itu bertahan lama, bahkan sampai pada taraf tertentu tidak akan lenyap begitu saja. Purba, dkk (2004) menyatakan bahwa hasil belajar dikatakan relatif menetap, karena ada kemungkinan suatu hasil belajar ditiadakan atau dihapuskan dan diganti dengan hal yang baru. Belajar itu dapat diartikan sebagai suatu proses perubahan tingkah laku dari yang tidak tahu menjadi tahu, yang diperoleh melalui proses latihan-latihan, pengalaman, keterampilan dan nilai sikap yang hasilnya bersifat relatif menetap (permanen).

Di dalam kegiatan belajar mengajar, terdapat keterampilan yang dapat digunakan seorang guru untuk memotivasi siswa, yaitu (a) Keterampilan guru memberi penguatan, (b) Keterampilan guru mengadakan variasi.

\section{Keterampilan Guru Memberi Penguatan (Reinforcement Skill)}

Jika seseorang telah melakukan sesuatu kegiatan terhadap orang lain, biasanya ia memperoleh penghargaan dalam beberapa bentuk, seperti ucapan terima kasih atau hadiah berupa materi. Dengan menerima penghargaan tersebut, orang yang melakukan kegiatan akan merasa puas, dan bagi orang yang menerima jasanya mengaharapkan agar kegiatan tersebut berulang kembali. Penghargaan yang dimaksud berguna sebagai penguat bagi yang menerimanya, agar mau melakukan hal yang sama di masa-masa yang akan datang.

Dalam kegiatan belajar mengajar, penghargaan yang diberikan itu disebut dengan penguatan. Penguatan dapat diartikan sebagai bentuk respon, baik yang bersifat verbal maupun non-verbal, terhadap sesuatu tingkah laku tersebut. Penghargaan yang diberikan guru kepada siswa, setelah menunjukkan tingkah laku yang baik, seperti anggukan kepala, 
senyum, kata-kata pujian, akan dapat menguatkan tingkah laku dan penampilan siswa untuk mengulanginya pada situasi-situasi lain. Pemberian penguatan secara bijaksana dan sistematik berdasarkan cara dan prinsip yang tepat, akan memberi manfaat bagi siswa untuk (1) Meningkatkan perhatian terhadap kegiatan belajarmengajar; (2) Memperoleh kemudahan dalam mengikuti penyajian guru; (3) Memelihara dan meningkatkan motivasi belajar yang tinggi; (4) Mengubah dan mengendalikan tingkah laku ke arah yang lebih produktif; (5) Mengembangkan dan mengatur diri sendiri dalam kegiatan belajar mengajarnya; (6) Mengarahkan cara berfikir ke tingkat yang lebih tinggi.

\section{Keterampilan Menggunakan Penguatan}

Ada beberapa keterampilan memberi penguatan yang perlu dipahami dan kuasai penggunaannya oleh guru agar dapat memberi penguatan secara bijaksana dan sistematik, yaitu (1) Penguatan verbal, yaitu penguatan yang diungkapkan dengan menggunakan katakata atau kalimat-kalimat pujian, penghargaan. (2) Penguatan non-verbal, yaitu penguatan yang diungkapkan tanpa menggunakan kata-kata, tetapi cukup dengan gerak isyarat, seperti mimik dan gerakan tubuh (senyuman, anggujan kepala); Cara mendekati siswa (berdiri di samping siswa); Sentuhan (menepuk-nepuk bahu, tetapi guru harus memperhatikan budaya yang berlaku di mana guru itu bekerja); Simbol atau benda dan kegiatan yang menyenangkan, yaitu melalui pemberian tugas yang disenangi siswa.

\section{Keterampilan Guru Mengadakan Variasi}

Tim UPPL UNIMED (2006) mengemukakan bahwa mengadakan variasi dalam proses belajar mengajar dapat diartikan sebagai proses pengubahan gaya mengajar guru yang bersifat personal, penggunaan media dan bahan-bahan instruksional, serta pola-pola interaksi guru dengan siswa dalam pengajaran. Keterampilan mengadakan variasi dalam gaya guru mengajar meliputi:

1) Gerak Guru (Teacher Movement). Gerak guru dimaksudkan sikap atau penampilan gerak badan guru dalam kelas. Jenis variasi ini dapat dipergunakan guru untuk mempertahankan perhatian siswa, terutama pada saat menghantarkan pelajaran di kelas.

2) Suara Guru (Teacher Voice). Dalam variasi ini guru mengadakan perubahan suara dari yang keras menjadi lemah, dari yang tinggi menjadi rendah, dari yang cepat menjadi lambat, dari yang gembira menjadi sedih, atau memberi penekanan suara pada katakata tertentu.

3) Guru Diam (Teacher Silent). Dalam hal ini guru sengaja dan tiba-tiba menciptakan atau menimbulkan kesenyapan sejenak selagi menerangkan sesuatu bahan kepada siswa. Keadaan tersebut diharapkan dapat mengundang perhatian serius dari siswa untuk mengetahui kelanjutan dari pembicaraan.

4) Kontak pandang dengan gerak (Eye contact and Movement). Kontak pandang dan gerak merupakan sesuatu kunci penyampaian ekspresi emosi. Dengan variasi tersebut, guru dapat menyampaikan informasi serta dapat mengetahui perhatian atau pemahaman siswa tentang apa yang disajikan.

5) Pemusatan Perhatian (Focusing). Dalam hal ini guru berupaya memusatkan perhatian siswa-siswa pada hal-hal yang dianggap penting.

6) Gaya Interaksi (Interaction Styles). Ada tiga macam gaya interaksi dalam kegiatan pembelajaran, yaitu Pola interaksi gurukelompok siswa/kelas; Pola interaksi gurusiswa sebagai individu; dan Pola interaksi siswa-siswa.

7) Pengalihan Penggunaan Indera (Switching Sensory Channels). Kemampuan siswa untuk menyerap dan memproses informasi dapat ditingkatkan bila proses belajar mengajar tidak bersifat monoton.

\section{Minat}

Minat adalah suatu rasa lebih suka dan rasa ketertarikan pada suatu hal atau aktivitas tanpa ada yang menyuruh. Minat pada dasarnya adalah penerimaan pada suatu hubungan antara diri sendri dengan sesuatu di luar diri. Semakin 
kuat atau dekat hubungan tersebut, semakin besar minat. Hilgard dalam Slameto (2003) memberi rumusan tentang minat, yaitu interest is persisting tendency to pay attention to enjoy some activity or content. Minat besar pengaruhnya terhadap belajar, karena bila bahan pelajaran yang dipelajari tidak sesuai dengan minat siswa, siswa tidak akan belajar dengan sebaik-baiknya, karena tidak ada daya tarik baginya. Bahan pelajaran yang menarik minat siswa, lebih mudah dipelajari dan disimpan, karena minat menambah kegiatan belajar.

Di samping memanfaatkan minat yang telah ada, Tanner dalam Slameto (2003) menyarankan agar para pengajar juga berusaha membentuk minat-minat baru pada diri siswa. Ini dapat dicapai dengan jalan memberikan informasi pada siswa mengenai hubungan suatu bahan pengajaran yang akan diberikan dengan pengajaran yang lalu, menguraikan kegunaannya bagi siswa di masa yang akan datang.

Sardiman (2006) mengemukakan motivasi sangat erat hubungannya dengan unsur minat. Motivasi muncul karena ada kebutuhan, begitu juga minat sehingga tepatlah kalau minat merupakan alat motivasi yang pokok. Proses pembelajaran itu akan berjalan lancar kalau disertai dengan minat. Mengenai minat antara lain dapat dibangkitkan dengan cara: (a) Membangkitkan adanya suatu kebutuhan; (b) Menghubungkan dengan persoalan pengalaman yang lampau; (c) Memberi kesempatan untuk mendapatkan hasil yang baik; (d) Menggunakan berbagai macam bentuk mengajar.

\section{Metode Penelitian}

Penelitian ini dilaksanakan di MTs Istiqlal Delitua Kabupaten Deli Serdang dan pelaksanaannya pada semester genap Tahun Pelajaran 2007/2008. Penelitian ini dikategorikan dalam penelitian deskriptif korelasi yaitu penelitian yang mendeskripsikan (memaparkan) ada tidaknya hubungan antara peranan gaya mengajar guru Fisika dengan minat siswa belajar Fisika. Populasi dalam penelitian ini adalah seluruh siswa kelas IX MTs Istiqlal Delitua yang terdiri dari tiga kelas. Karena siswa kelas IX MTs Istiqlal Delitua terdiri dari tiga kelas, maka yang dijadikan sampel penelitian ada dua kelas, tiap kelas terdiri dari 35 siswa.

\section{Prosedur Penelitian}

\section{Tahap Persiapan}

Pada tahap ini peneliti mempersiapkan yang diperlukan dalam penelitian (anatara lain: surat izin penelitian, memvalidkan angket kepada seorang dosen yang ahli dibidangnya).

\section{Tahap Pelaksanaan}

Pada tahap ini peneliti mengunjungi tempat penelitian. Untuk mendapatkan data tentang gambaran peranan gaya mengajar guru Fisika dan data tentang minat belajar Fisika siswa, maka peneliti memberikan angket kepada siswa kelas IX MTs di dalam kelas.

\section{Hasil Penelitian dan Pembahasan}

Karena data yang diperoleh dengan penyebaran angket, maka untuk kedua variabel yaitu variabel peranan gaya mengajar guru Fisika dan variabel minat belajar Fisika. Angket ini menggunakan model jawaban Ya dan Tidak. setiap option jawaban dari pertanyaan positif diberi bobot nilai 5 jika jawaban (a) atau Ya, dan diberi nilai 0 jika jawaban (b) atau tidak.

Tabel 1. Persentase tiap indikator variabel gaya mengajar guru Fisika

\begin{tabular}{|c|c|c|c|c|c|}
\hline \multirow[b]{2}{*}{$\begin{array}{l}\text { No } \\
\text { soal }\end{array}$} & \multicolumn{2}{|c|}{ Frekuensi tiap soal } & \multirow[b]{2}{*}{$\begin{array}{l}\text { Total } \\
\text { skor }\end{array}$} & \multicolumn{2}{|c|}{ Persentase tiap soal } \\
\hline & $\begin{array}{c}\text { Jawaban } \\
\text { Ya }\end{array}$ & $\begin{array}{c}\text { Jawaban } \\
\text { Tidak }\end{array}$ & & $\begin{array}{c}\text { Jawaban } \\
\text { Ya }\end{array}$ & $\begin{array}{c}\text { Jawaban } \\
\text { Tidak }\end{array}$ \\
\hline 1 & 48 & 22 & 70 & 68,6 & 31,4 \\
\hline 2 & 43 & 27 & 70 & 61,4 & 38,6 \\
\hline 3 & 65 & 5 & 70 & 92,9 & 7,1 \\
\hline 4 & 40 & 30 & 70 & 57,1 & 42,9 \\
\hline
\end{tabular}




\begin{tabular}{|c|c|c|c|c|c|}
\hline 5 & 49 & 21 & 70 & 70 & 30 \\
\hline 6 & 43 & 27 & 70 & 61,4 & 38,6 \\
\hline 7 & 40 & 30 & 70 & 57,1 & 42,9 \\
\hline 8 & 62 & 8 & 70 & 88,6 & 11,4 \\
\hline 9 & 64 & 6 & 70 & 91,4 & 8,6 \\
\hline 10 & 54 & 26 & 70 & 77,1 & 22,9 \\
\hline 11 & 65 & 5 & 70 & 92,9 & 7,1 \\
\hline 12 & 44 & 26 & 70 & 62,9 & 37,1 \\
\hline 13 & 62 & 8 & 70 & 88,6 & 11,4 \\
\hline 14 & 44 & 26 & 70 & 62,9 & 37,1 \\
\hline 15 & 65 & 5 & 70 & 92,9 & 7,1 \\
\hline 16 & 69 & 1 & 70 & 98,6 & 1,4 \\
\hline 17 & 43 & 27 & 70 & 61,4 & 38,6 \\
\hline 18 & 52 & 18 & 70 & 74,3 & 25,7 \\
\hline 19 & 52 & 18 & 70 & 74,3 & 25,7 \\
\hline 20 & 50 & 20 & 70 & 71,4 & 28,6 \\
\hline
\end{tabular}

Sumber: Hasil Pengolahan Data Penelitian

\section{Temuan Penelitian}

Dari hasil analisis data ada beberapa temuan penelitian, yaitu:

1. Nilai rata-rata skor peranan gaya mengajar guru Fisika adalah 74,86.

2. Nilai rata-rata skor minat belajar Fisika siswa adalah 70,57.

3. Besarnya koefisien korelasi $\mathrm{X}$ dan $\mathrm{Y}$ adalah 0,596 . Ini berarti besarnya hubungan antara peranan gaya mengajar guru fisika terhadap minat belajar Fisika siswa sebesar 0,596.

4. Indikator Gerak Guru (Teacher Movement) yang terdiri dari nomor 1, 2, dan 3, dengan rincian skor jawaban no. $1=48$ siswa, skor jawaban no. $2=43$ siswa dan skor jawaban no. $3=65$ siswa. Maka jumlah keseluruhan indikator Gerak Guru (Teacher Movement) adalah 156. Sehingga persentase rata-rata indikator gerak guru (Teacher Movement) adalah $74,3 \%$.

5. Indikator Suara Guru (Teacher Voice) yang terdiri dari nomor 4 dan 5, dengan rincian skor jawaban no. $4=40$ siswa $(51,7 \%)$, dan skor jawaban no. $5=49$ siswa $(70 \%)$. Maka jumlah keseluruhan indikator Suara Guru (Teacher Voice) adalah 89. Sehingga persentase rata-rata indikator Suara Guru (Teacher Voice) adalah 63,6\%.

6. Indikator Guru Diam (Teacher Silence) yang hanya terdiri dari no. 6 , dengan rincian skor jawaban no. $6=43$ siswa $(61,4 \%)$. Maka jumlah keseluruhan indikator Guru Diam (Teacher Silence) adalah 43. Sehingga persentase rata-rata indikator Guru Diam (Teacher Silence) adalah 61,4\%.

7. Indikator Kontak Pandang dengan Gerak (Eye Contact and Movement) yang hanya terdiri dari no. 7, dengan rincian skor jawaban no. $7=40$ siswa $(57,1 \%)$. Maka jumlah keseluruhan ndikator Kontak Pandang dengan Gerak (Eye Contact and Movement) adalah 40. Sehingga persentase rata-rata indikator Kontak Pandang dengan Gerak (Eye Contact and Movement) adalah $57,1 \%$.

8. Indikator Kontak Pandang dengan Gerak (Eye Contact and Movement) yang hanya terdiri dari no. 7, dengan rincian skor jawaban no. $7=40$ siswa $(57,1 \%)$. Maka jumlah keseluruhan ndikator Kontak Pandang dengan Gerak (Eye Contact and Movement) adalah 40. Sehingga persentase rata-rata indikator Kontak Pandang dengan Gerak (Eye Contact and Movement) adalah 57,1\%.

9. Indikator Gaya Interaksi (Interaction Style) yang terdiri dari nomor 11, 12, 13, 14, 15, 16, 17,18, dan 19, dengan rincian skor jawaban no. $11=65$ siswa, skor jawaban no. $12=44$ siswa, skor jawaban no. $13=62$ siswa, skor jawaban no. $14=44$ siswa, skor 
jawaban no. $15=65$ siswa, skor jawaban no. $16=52$ siswa, skor jawaban no. $17=69$ siswa, skor jawaban no. $18=43$ siswa, dan skor jawaban no. $19=52$ siswa. Maka jumlah keseluruhan indikator Gaya Interaksi (Interaction Style) adalah 496. Sehingga persentase rata-rata indikator Gaya Interaksi (Interaction Style) adalah 78,7\%.

10. Indikator Pengalihan Penggunaan Indera (Switching Sensory Channels) yang hanya terdiri dari no. 20, dengan rincian skor jawaban no. $20=50$ siswa $(71,4 \%)$. Maka jumlah keseluruhan indikator Pengalihan Penggunaan Indera (Switching Sensory Channels) adalah 50. Sehingga persentase rata-rata indikator Pengalihan Penggunaan Indera (Switching Sensory Channels) adalah $71,4 \%$.

\section{Pembahasan}

Dari hasil penelitian diperoleh ada pengaruh yang positif dari Peranan Gaya Mengajar Guru Fisika terhadap Minat Belajar Fisika Siswa. Ini berarti semakin banyak variasi atau gaya mengajar guru kepada siswa maka diharapkan minat siswa belajar Fisika semakin meningkat. Dalam pembelajaran Fisika, variasi gaya mengajar atau motivasi dari seorang guru merupakan salah satu faktor yang sangat penting. Penguatan yang baik dan tepat dari seorang guru menambah rasa gairah, rasa aman, semangat, dan perasaan senang siswa dalam mempelajari Fisika sehingga dapat meningkatkan minat belajar siswa pada pelajaran Fisika. Akan tetapi masih banyak faktor-faktor yang dapat mempengaruhi prestasi belajar siswa seperti intelegensi siswa, bakat siswa dipelajaran Fisika, ekonomi keluarga, keluarga harmonis, keadaan tempat tinggal dan kondisi kesehatan.

Untuk mengatasi hal tersebut, dalam hal ini pihak sekolah semestinya mengyediakan sarana dan prasarana yang memadai seperti sarana perpustakaan, laboratorium, ruang kesehatan dan ruang bimbingan konseling beserta konselor. Perpustakaan sekolah dapat digunakan siswa untuk menambah wawasan ilmu pengetahuan khususnya Fisika dengan membaca buku di perpustakaan sehingga siswa yang tidak mampu membeli buku pelajaran selain dari buku paket sekolah dapat membacanya melalui buku yang ada di perpustakaan. Fasilitas laboratorium dapat digunakan siswa untuk menerapkan, mengaplikasikan teori yang didapat atau yang telah dijelaskan oleh guru di kelas.

\section{Simpulan}

Simpulan dari penelitian ini adalah (1) Nilai rata-rata angket gaya mengajar guru Fisika pada siswa kelas IX MTs Istiqlal Delitua semester genap tahun pelajaran 2007/2008 adalah 74,86. (2) Nilai rata-rata angket minat para siswa kelas IX MTs Istiqlal Delitua terhadap pelajaran Fisika adalah 70,57 bila guru Fisika memvariasikan gaya mengajar pada siswa. (3) Ada peranan yang positif dan signifikan dari peranan gaya mengajar guru Fisika dalam proses pembelajaran terhadap minat siswa kelas IX MTs Istiqlal Delitua semester genap tahun pelajaran 2007/2008 untuk belajar Fisika dengan koefisien korelasinya 0,596 .

\section{Daftar Pustaka}

Edward, P., dkk. 2004. Belajar dan Pembelajaran. Medan. Unimed.

Sardiman, A.M. 2006. Interaksi dan motivasi belajar mengajar. Jakarta: Raja grafindo persada.

Slameto. 2006. Belajar dan faktor-faktor yang mempengaruhinya. Jakarta. Rineka cipta.

TIM UPPL UNIMED. 2006. Micro teaching berbasis kompetensi. Medan. UPPL Unimed. 